\title{
Prauserella muralis sp. nov., from the indoor environment
}

\author{
Correspondence \\ P. Kämpfer \\ peter.kaempfer@umwelt. \\ uni-giessen.de
}

\author{
Jenny Schäfer, ${ }^{1}$ Karin Martin ${ }^{2}$ and Peter Kämpfer ${ }^{1}$ \\ ${ }^{1}$ Institut für Angewandte Mikrobiologie, Justus-Liebig-Universität Giessen, D-35392 Giessen, \\ Germany \\ ${ }^{2}$ Leibniz-Institut für Naturstoff-Forschung und Infektionsbiologie e.V., Hans-Knöll-Institut für \\ Naturstoff-Forschung e.V., D-07745 Jena, Germany
}

A novel Gram-stain-positive, mycelium-forming actinobacterium $\left(05-\mathrm{Be}-005^{\top}\right)$ isolated from the wall of an indoor environment was studied for its taxonomic position. The isolated strain formed a substrate mycelium that fragmented into rod-shaped cells and showed an aerial mycelium on medium M79. On the basis of $16 \mathrm{~S}$ rRNA gene sequence similarity studies, strain $05-\mathrm{Be}-005^{\top}$ was shown to belong to the genus Prauserella, closely related to Prauserella rugosa DSM $43194^{\top}$ (96.6\% similarity), Prauserella alba YIM 90005 ${ }^{\top}$ (95.9\%) and Prauserella halophila YIM $90001^{\top}(95.4 \%)$. The predominant menaquinone was MK-9 $\left(\mathrm{H}_{4}\right)$; whole-cell hydrolysates contained meso-diaminopimelic acid as the diagnostic diamino acid of the cell wall and arabinose and galactose as the main sugars. Mycolic acids were absent. The polar lipid profile consisted of the lipids diphosphatidylglycerol, phosphatidylglycerol, phosphatidylethanolamine, phosphatidylmethylethanolamine, phosphatidylinositol, phosphatidylserine and an unknown phospholipid. Major fatty acids $\mathrm{C}_{16: 0}$ iso, $\mathrm{C}_{16: 0}, \mathrm{C}_{17: 1} \omega 8 \mathrm{c}$ and $\mathrm{C}_{17: 1} \omega 6 c$ supported the affiliation of strain $05-\mathrm{Be}-005^{\top}$ to the genus Prauserella. The results of physiological and biochemical tests allowed clear phenotypic differentiation of strain $05-\mathrm{Be}-005^{\top}$ from the three known Prauserella species. Strain $05-\mathrm{Be}-005^{\top}$ represents a novel Prauserella species, for which we propose the name Prauserella muralis sp. nov., with the type strain 05-Be-005 ${ }^{\top}$ (=CCUG

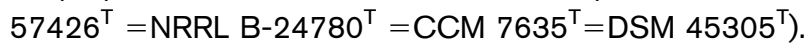

The genus Prauserella was described by Kim \& Goodfellow (1999) to accommodate the single species Prauserella rugosa, which had originally been classified in the genus Amycolatopsis. P. rugosa was found to form a substrate mycelium that undergoes fragmentation. The type strain contained meso-diaminopimelic acid (meso- $\mathrm{A}_{2} \mathrm{pm}$ ), arabinose and galactose (chemotype IV sensu Lechevalier et al., 1977), as well as a complex mixture of branched-chain and saturated fatty acids, it lacked mycolic acids, had di- and tetrahydrogenated menaquinones with nine isoprene units as the predominant isoprenologues and contained major amounts of diphosphatidylglycerol, phosphatidylglycerol, phosphatidylinositol, phosphatidylethanolamine and phosphatidylmethylethanolamine. Li et al. (2003) described two additional Prauserella species, sharing most of these chemotaxonomic features.

Strain $05-\mathrm{Be}-005^{\mathrm{T}}$ was isolated from a wall colonized with moulds. After extraction of a $1 \mathrm{~g}$ sample by shaking for $15 \mathrm{~min}$

Abbreviations: $\mathrm{A}_{2} \mathrm{pm}$, diaminopimelic acid; pNA, p-nitroanilide; pNP, p-nitrophenyl.

The GenBank/EMBL/DDBJ accession number for the $16 \mathrm{~S}$ rRNA gene sequence of strain $05-\mathrm{Be}-005^{\top}$ is $\mathrm{FM956091.}$ in $10 \mathrm{ml} 0.9 \% \mathrm{NaCl}$ solution containing $0.01 \%(\mathrm{v} / \mathrm{v})$ Tween 80 , aliquots of the suspension were spread on agar plates containing mineral agar according to Gauze et al. (1983) (containing $\mathrm{l}^{-1}: 20 \mathrm{~g}$ soluble starch, $1 \mathrm{~g} \mathrm{KNO}_{3}, 0.5 \mathrm{~g} \mathrm{~K}_{2} \mathrm{HPO}_{4}$, $0.5 \mathrm{~g} \mathrm{MgSO}_{4} \cdot 7 \mathrm{H}_{2} \mathrm{O}, 0.5 \mathrm{~g} \mathrm{NaCl}, 0.01 \mathrm{~g} \mathrm{FeSO}_{4} \cdot 7 \mathrm{H}_{2} \mathrm{O}, 20 \mathrm{~g}$ agar). The agar plates were incubated for 2 weeks at $28{ }^{\circ} \mathrm{C}$. The isolated strain was maintained on organic medium M79 [containing $\mathrm{l}^{-1}$ : $10 \mathrm{~g}$ glucose, $10 \mathrm{~g}$ peptone (Bacto), $2 \mathrm{~g}$ casein hydrolysate, $2 \mathrm{~g}$ yeast extract, $6 \mathrm{~g} \mathrm{NaCl}, 15 \mathrm{~g}$ agar; http:// www.dsmz.de] and preserved at $-80{ }^{\circ} \mathrm{C}$ as a $1: 1$ mixture of well-growing cultures in M79 broth and glycerol preservation medium (Chakrabarty \& Brown, 1978). The strain formed grey, slightly orange-coloured substrate mycelium and white aerial mycelium on M79 at $28{ }^{\circ} \mathrm{C}$.

Morphological properties, Gram staining and cell morphology were observed microscopically as described by Kämpfer \& Kroppenstedt (2004). Isolation of the DNA was performed with a commercial DNA extraction kit (GenElute plant genomic DNA kit; Sigma) after disruption of cells by a $1 \mathrm{~min}$ bead-beating step with $1 \mathrm{~g}$ of $0.1 \mathrm{~mm}$ diameter zirconia beads at maximum speed.

Multiple sequence alignment and analysis of the data were performed using the software package MEGA version 4 


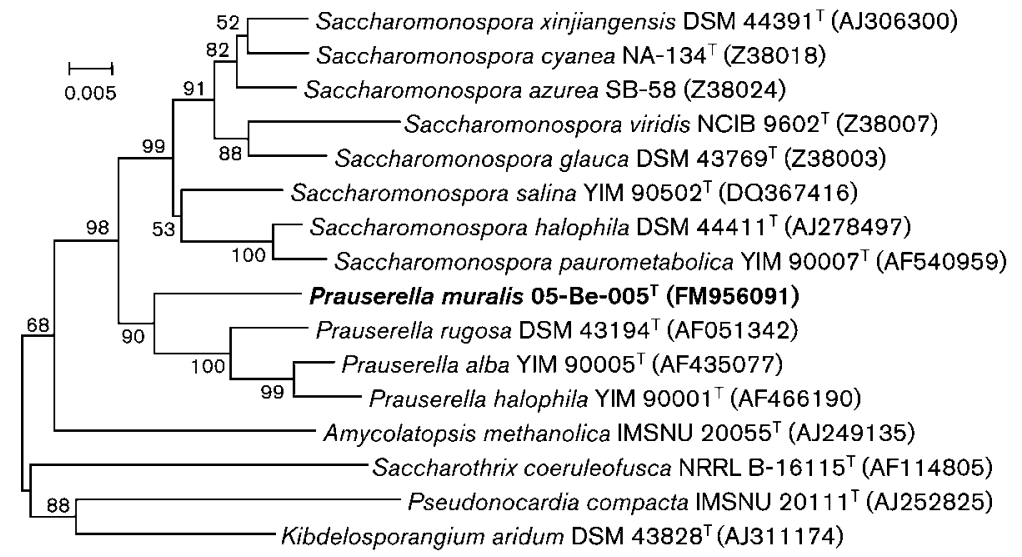

Fig. 1. Phylogenetic analysis based on $16 \mathrm{~S}$ rRNA gene sequences available from the EMBL database (accession numbers in parentheses) showing the position of strain 05Be-005 ${ }^{\top}$. Multiple alignment, distance calculations (distance options according to the Kimura-2 model) and clustering with the neighbour-joining method were performed by using the software package MEGA version 4 (Tamura et al., 2007). Bootstrap values based on 1000 replications are listed as percentages at branching points. Bar, 0.005 substitutions per nucleotide position.
(Tamura et al., 2007). Genetic distance calculations (distance options according to Kimura's two-parameter model; Kimura, 1980) and clustering with the neighbourjoining method (Fig. 1) were performed by using bootstrap values based on 1000 replications. The 16S rRNA gene sequence of strain $05-\mathrm{Be}-005^{\mathrm{T}}$ was a continuous stretch of 1412 bp. Sequence similarity calculations after a neighbour-joining analysis indicated that the closest relatives of strain $05-\mathrm{Be}-005^{\mathrm{T}}$ were P. rugosa DSM $43194^{\mathrm{T}}(96.6 \%$ similarity), Prauserella alba YIM $90005^{\mathrm{T}}(95.9 \%)$ and Prauserella halophila YIM $90001^{\mathrm{T}}(95.4 \%)$.

Standard paper chromatography, HPLC and TLC procedures were used to determine the quinone system (Collins et al., 1977; Groth et al., 1996), whole-organism sugars (Becker et al., 1965) and polar lipids (Minnikin et al., 1979). Analysis of the amino acids in peptidoglycan hydrolysates was carried out according to Schleifer \& Kandler (1972) and as described by Groth et al. (1996). Menaquinones were extracted and analysed as described by Collins et al. (1977). Polar lipids extracted by the method of Minnikin et al. (1979) were identified by twodimensional TLC as described by Collins et al. (1980). The occurrence of mycolic acids was determined by TLC as described by Minnikin et al. (1975). For all chemotaxonomic analyses except for fatty acid analyses, cells were grown for $24-48 \mathrm{~h}$ in shake flasks in liquid organic medium M79 at 180 r.p.m. at $28{ }^{\circ} \mathrm{C}$; for fatty acid analyses, cells were grown on tryptic soy agar. Fatty acid analysis was performed according to Kämpfer \& Kroppenstedt (1996).

Whole-organism hydrolysates of strain $05-\mathrm{Be}-005^{\mathrm{T}}$ contained meso- $\mathrm{A}_{2} \mathrm{pm}$ as the diagnostic diamino acid of the peptidoglycan and the sugars arabinose, galactose and glucose (wall chemotype IV sensu Lechevalier \& Lechevalier, 1970), typical of members of the genus Prauserella. The predominant menaquinone was MK$9\left(\mathrm{H}_{4}\right)(79 \%)$; minor amounts of MK-8 $\left(\mathrm{H}_{4}\right)(5 \%)$ and MK-8 $(6 \%)$ and traces of other menaquinones $(<3 \%)$ were also detected.

The phospholipids were composed of diphosphatidylglycerol, phosphatidylglycerol, phosphatidylethanolamine, phosphatidylmethylethanolamine and phosphatidylinositol; these phospholipids were also present in the three described Prauserella species. Additionally, phosphatidylserine and an unknown phospholipid were detected. Mycolic acids were absent.

The fatty acid profile of strain $05-\mathrm{Be}-005^{\mathrm{T}}$ was very similar to those of the type strains of the closely related species $P$. rugosa, $P$. alba and P. halophila and was congruent with the fatty acid profiles reported by Li et al. (2003), although some quantitative and also qualitative differences could be observed (Table 1).

Table 1. Major fatty acids of type strains of species of the genus Prauserella

Strains: $1,05-\mathrm{Be}-005^{\mathrm{T}} ; 2$, P. alba DSM $44590^{\mathrm{T}} ; 3$, P. rugosa DSM $43194^{\mathrm{T}}$; 4, P. halophila DSM $44617^{\mathrm{T}}$. Data were obtained in this study; values are percentages of total fatty acids. -, Not detected.

\begin{tabular}{|lcccc|}
\hline Fatty acid & $\mathbf{1}$ & $\mathbf{2}$ & $\mathbf{3}$ & $\mathbf{4}$ \\
\hline $\mathrm{C}_{14: 0}$ iso & 0.7 & 0.9 & - & 1.2 \\
$\mathrm{C}_{14: 0}$ iso & 0.6 & 0.6 & - & - \\
$\mathrm{C}_{15: 0}$ iso & 2.0 & 1.8 & 1.1 & 1.8 \\
$\mathrm{C}_{15: 1} \omega 6 c$ & 2.2 & - & 1.0 & 2.2 \\
$\mathrm{C}_{15: 0}$ & 6.0 & 1.4 & 1.3 & 2.2 \\
$\mathrm{C}_{16: 1}$ iso H & 4.0 & 5.2 & 14.4 & 4.1 \\
$\mathrm{C}_{16: 0}$ iso & 36.5 & 27.7 & 34.9 & 27.0 \\
Summed feature $3^{*}$ & 6.2 & 11.4 & 6.4 & 11.0 \\
$\mathrm{C}_{16: 0}$ & 9.5 & 17.8 & 4.6 & 8.0 \\
$\mathrm{C}_{16: 0} 10-$ methyl & 4.1 & - & 2.3 & - \\
$\mathrm{C}_{17: 0}$ iso & 2.0 & 1.9 & 2.7 & 1.6 \\
$\mathrm{C}_{17: 0}$ anteiso & 2.9 & 5.4 & 3.4 & 10.6 \\
$\mathrm{C}_{17: 1} \omega 8 c$ & 5.5 & 4.9 & 4.3 & 8.7 \\
$\mathrm{C}_{17: 1} \omega 6 c$ & 8.7 & 8.8 & 15.6 & 11.0 \\
$\mathrm{C}_{17: 0}$ & 7.2 & 4.7 & 2.9 & 3.7 \\
$\mathrm{C}_{17: 0}$ 10-methyl & 1.5 & - & - & - \\
$\mathrm{C}_{18: 1}$ iso & - & 1.3 & 1.0 & 3.7 \\
$\mathrm{C}_{18: 1} \omega 9 c$ & - & 1.9 & 1.9 & 2.2 \\
$\mathrm{C}_{18: 0}$ & - & 4.1 & 2.1 & - \\
& & & & \\
\hline
\end{tabular}

${ }^{\star}$ Summed feature 3 contains $\mathrm{C}_{16: 1} \omega 7 c$ and/or $\mathrm{C}_{15: 0}$ iso $2-\mathrm{OH}$. 
Table 2. Physiological characteristics of the type strains of Prauserella species

Strains: $1,05-\mathrm{Be}-005^{\mathrm{T}} ; 2$, P. alba DSM $44590^{\mathrm{T}} ; 3$, P. rugosa DSM $43194^{\mathrm{T}}$; 4, P. halophila DSM $44617^{\mathrm{T}}$. +, Positive; - , negative; $(+)$, weakly positive. Data were obtained in this study under identical conditions. All strains were negative for hydrolysis of aesculin, $o$-nitrophenyl $\beta$-D-galactopyranoside, $p$-nitrophenyl (pNP) $\beta$-Dglucuronide, bis-pNP phosphate, pNP phenylphosphonate, $\mathrm{pNP}$ phosphorylcholine, L-alanine $p$-nitroanilide (pNA), L-glutamate $\gamma$-3carboxy-pNA and L-proline pNA and utilization of $N$-acetyl-Dgalactosamine, $\alpha$-melibiose, $p$-arbutin $\dagger$, salicin, inositol $\dagger$, maltitol, mesaconate, putrescine, $\beta$-alanine, L-tryptophan and 3-hydroxybenzoate. All strains were positive for utilization of cellobiose ${ }^{\star} \dagger$, D-fructose $e^{\star} \dagger$, D-glucose $e^{\star} \dagger$, D-galactose $\dagger$, L-rhamnose $e^{\star} \dagger$, ribose ${ }^{\star} \dagger$, D-xylose ${ }^{\star} \dagger$, adonitol, D-mannitol ${ }^{\star} \dagger$, acetate, propionate $\dagger$, fumarate, 3-hydroxy-DL-butyrate, L-malate, pyruvate $\dagger$, suberate, L-alanine ${ }^{\star} \dagger$, L-histidine, L-phenylalanine and L-proline ${ }^{\star} \dagger$.

\begin{tabular}{|c|c|c|c|c|}
\hline Test & 1 & 2 & 3 & 4 \\
\hline \multicolumn{5}{|l|}{ Hydrolysis of: } \\
\hline pNP $\alpha$-D-glucopyranoside & + & + & + & - \\
\hline pNP $\beta$-D-glucopyranoside & - & - & + & - \\
\hline pNP $\beta$-D-xylopyranoside & + & - & - & - \\
\hline 2-Deoxythymidine-5'-pNP phosphate & - & - & + & - \\
\hline \multicolumn{5}{|l|}{ Assimilation of: } \\
\hline$N$-Acetyl-D-glucosamine & + & + & - & - \\
\hline L-Arabinose & + & $+^{*}$ & $+{ }^{*} \dagger$ & $-*$ \\
\hline D-Mannose & + & + & - & - \\
\hline Maltose & + & $(+)^{*}$ & $+{ }^{\star} \dagger$ & $-{ }^{*}$ \\
\hline Trehalose & + & + & $+\dagger$ & - \\
\hline D-Sorbitol & + & - & $-\dagger$ & + \\
\hline cis-Aconitate & + & + & + & - \\
\hline trans-Aconitate & + & + & + & - \\
\hline Adipate & - & + & + & + \\
\hline 4-Aminobutyrate & + & - & + & - \\
\hline Azelate & + & - & + & + \\
\hline Citrate & - & + & + & - \\
\hline Glutarate & - & - & + & - \\
\hline Itaconate & + & - & - & - \\
\hline DL-Lactate & + & + & + & - \\
\hline Oxoglutarate & + & + & - & - \\
\hline L-Aspartate & + & - & - & + \\
\hline L-Leucine & + & + & + & - \\
\hline L-Ornithine & + & - & - & - \\
\hline L-Serine & + & + & $-\dagger$ & - \\
\hline 4-Hydroxybenzoate & - & - & + & - \\
\hline Phenylacetate & + & + & + & - \\
\hline
\end{tabular}

${ }^{*}$ Data congruent with results for $P$. rugosa, $P$. alba and P. halophila given by Li et al. (2003).

$\dagger$ Data congruent with results for P. rugosa given by Kim \& Goodfellow (1999).

Results of the comparative physiological characterization, using identical test conditions in all cases, are given in Table 2 and the species description, with methods described previously (Kämpfer et al., 1991). Several test results were obtained which enable the differentiation of strain $05-\mathrm{Be}-005^{\mathrm{T}}$ from the other Prauserella type strains. We did not perform DNA-DNA hybridizations because of the low 16S rRNA gene sequence similarities $(<97 \%)$ to all other type strains of Prauserella. The isolate forms an aerial mycelium and contains only minor amounts $(<1.5 \%)$ of MK-9 $\left(\mathrm{H}_{2}\right)$, characteristics which are in agreement with the description of the genus Prauserella after its emendation by Li et al. (2003). Kim \& Goodfellow (1999) already described the high phenotypic similarity of $P$. rugosa to Saccharomonospora. In fact, the two genera can only be separated clearly on the basis of the 16S rRNA gene sequence dissimilarity, and strain $05-\mathrm{Be}-005^{\mathrm{T}}$ clustered clearly with the other known Prauserella species. The observed genotypic and phenotypic differences (Tables 1 and 2) warrant the creation of a novel species of the genus Prauserella.

\section{Description of Prauserella muralis sp. nov.}

Prauserella muralis (mu.ra'lis. L. fem. adj. muralis pertaining or belonging to walls).

Forms mycelium-like filaments, about $1.3 \mu \mathrm{m}$ wide. Substrate mycelium on M79 agar is grey to slightly orange. Aerial mycelium on agar is white and becomes fragmented. Gram-stain-positive, oxidase-positive (weak reaction), showing an oxidative metabolism. Good growth occurs after 3 days of incubation on tryptone soy agar and nutrient agar at $25-30{ }^{\circ} \mathrm{C}$. The quinone system is composed of the predominant compound menaquinone MK-9 $\left(\mathrm{H}_{4}\right)$. The polar lipid profile consists of diphosphatidylglycerol, phosphatidylglycerol, phosphatidylethanolamine, phosphatidylmethylethanolamine, phosphatidylinositol, phosphatidylserine and an unknown phospholipid (phospholipid pattern II sensu Lechevalier et al., 1977). Major fatty acids are $\mathrm{C}_{16: 0}$ iso, $\mathrm{C}_{16: 0}, \mathrm{C}_{17: 1} \omega 8 c$ and $\mathrm{C}_{17: 1} \omega 6 \mathrm{c}$. Carbon source utilization (including differentiating characters using identical conditions in all cases) is indicated in Table 2.

The type strain, $05-\mathrm{Be}-005^{\mathrm{T}}$ (=CCUG $57426^{\mathrm{T}}=\mathrm{NRRL}$ $\mathrm{B}-24780^{\mathrm{T}}=\mathrm{CCM} 7635^{\mathrm{T}}=\mathrm{DSM} 45305^{\mathrm{T}}$ ), was isolated in Berlin, Germany, by Dr C. Trautmann, sampled from the wall of a house colonized with moulds.

\section{Acknowledgements}

We are grateful to Carmen Schult and Gundula Will for excellent technical assistance and Jean Euzéby for support with the nomenclature. The study was supported in part by the Federal Environment Agency (Umweltbundesamt), grant no. FKZ 20562236.

\section{References}

Becker, B., Lechevalier, M. P. \& Lechevalier, H. A. (1965). Chemical composition of cell-wall preparations from strains of various formgenera of aerobic actinomycetes. Appl Microbiol 13, 236-243.

Chakrabarty, A. M. \& Brown, J. F. (1978). Microbial genetic engineering by natural plasmid transfer. In Genetic Engineering, pp. 
185-193. Edited by A. M. Chakrabarty. West Palm Beach, FL: CRC Press.

Collins, M. D., Pirouz, T., Goodfellow, M. \& Minnikin, D. E. (1977). Distribution of menaquinones in actinomycetes and corynebacteria. J Gen Microbiol 100, 221-230.

Collins, M. D., Goodfellow, M. \& Minnikin, D. E. (1980). Fatty acid, isoprenoid quinone and polar lipid composition in the classification of Curtobacterium and related taxa. J Gen Microbiol 118, 29-37.

Gauze, G. F., Preobrazhenskaya, T. P., Sveshnikova, M. A., Terekova, L. P. \& Maksimova, T. S. (1983). Opredelitel'Aktinomycetov. Rody Streptomyces, Streptoverticillium, Chainia. Moscow: Izd. Nauka (in Russian).

Groth, I., Schumann, P., Weiss, N., Martin, K. \& Rainey, F. A. (1996). Agrococcus jenensis gen. nov., sp. nov., a new genus of actinomycetes with diaminobutyric acid in the cell wall. Int J Syst Bacteriol 46, 234-239.

Kämpfer, P. \& Kroppenstedt, R. M. (1996). Numerical analysis of fatty acid patterns of coryneform bacteria and related taxa. Can J Microbiol 42, 989-1005.

Kämpfer, P. \& Kroppenstedt, R. M. (2004). Pseudonocardia benzenivorans sp. nov. Int J Syst Evol Microbiol 54, 749-751.

Kämpfer, P., Steiof, M. \& Dott, W. (1991). Microbiological characterisation of a fuel-oil contaminated site including numerical identification of heterotrophic water and soil bacteria. Microb Ecol 21, 227-251.

Kim, S. B. \& Goodfellow, M. (1999). Reclassification of Amycolatopsis rugosa Lechevalier et al. 1986 as Prauserella rugosa gen. nov., comb. nov. Int J Syst Bacteriol 49, 507-512.
Kimura, M. (1980). A simple method for estimating evolutionary rates of base substitutions through comparative studies of nucleotide sequences. J Mol Evol 16, 111-120.

Lechevalier, M. P. \& Lechevalier, H. A. (1970). Chemical composition as a criterion in the classification of aerobic actinomycetes. Int J Syst Bacteriol 20, 435-443.

Lechevalier, M. P., De Bièvre, C. \& Lechevalier, H. A. (1977). Chemotaxonomy of aerobic actinomycetes: phospholipid composition. Biochem Syst Ecol 5, 249-260.

Li, W.-J., Xu, P., Tang, S.-K., Xu, L.-H., Kroppenstedt, R. M., Stackebrandt, E. \& Jiang, C.-L. (2003). Prauserella halophila sp. nov. and Prauserella alba sp. nov., moderately halophilic actinomycetes from saline soil. Int J Syst Evol Microbiol 53, 1545-1549.

Minnikin, D. E., Alshamaony, L. \& Goodfellow, M. (1975). Differentiation of Mycobacterium, Nocardia, and related taxa by thin-layer chromatographic analysis of whole-organism methanolysates. J Gen Microbiol 88, 200-204.

Minnikin, D. E., Collins, M. D. \& Goodfellow, M. (1979). Fatty acid and polar lipid composition in the classification of Cellulomonas, Oerskovia and related taxa. J Appl Bacteriol 47, 87-95.

Schleifer, K. H. \& Kandler, O. (1972). Peptidoglycan types of bacterial cell walls and their taxonomic implications. Bacteriol Rev 36, 407-477.

Tamura, K., Dudley, J., Nei, M. \& Kumar, S. (2007). MEGA4: molecular evolutionary genetics analysis (MEGA) software version 4.0. Mol Biol Evol 24, 1596-1599. 